S.V. Surkov, PhD, Assoc. Prof., Hussam Ghanem

Odessa National Polytechnic University, 1 Shevchenko Ave., Odessa, Ukraine, 65044; e-mail: surkov101@mail.ru

\title{
OPTIMAL OPERATIONAL REGIMES OF SEA WATER DESALINATION PLANTS WITH MECHANICAL VAPOR COMPRESSION
}

\begin{abstract}
С.В. Сурков, Хуссам Ганем. Оптимальні режими роботи опріснювачів морської води з механічним стисненням пари. Опріснення морської води стає дедалі більш актуальним для багатьох регіонів. В найближчі десятиріччя для опріснення буде використовуватись вода з різних водойм Світового океану. Важливо визначити режими роботи опріснювальних установок, які забезпечують мінімальну собівартість опрісненої води при різній солоності морської води. Виконано математичне моделювання опріснювальної установки з механічним стисненням пари (MVC). Встановлено, що для кожного значення солоності морської води існує оптимальне значення солоності киплячого розсолу в випарнику. Отримано апроксимуючу залежність для розрахунку оптимального вмісту солі.

Ключові слова: опріснення морської води, механічне стиснення пари, чисельне моделювання

S.V. Surkov, Hussam Ghanem. Optimal operational regimes of sea water desalination plants with mechanical vapor compression. Desalination of sea water is becoming more urgent for many regions. In the coming decades water will be used for desalination from various reservoirs of the World Ocean. It is important to determine the operating modes of desalination plants, which ensure the minimum cost of desalinated water at different salinity of sea water. Mathematical modeling of the desalination plant with mechanical vapor compression (MVC) is carried out. It has been established that for each sea water salinity there is an optimum salinity value of the boiling brine in the evaporator. An approximating dependence was obtained for calculating the optimal salt content.

Keywords: seawater desalination, mechanical vapor compression, numerical modeling
\end{abstract}

Introduction. According to analysts' forecasts, in the coming decades freshwater will become one of the scarcest resources in the world. More and more countries and regions will consume desalinated water [1]. This problem will also affect southern Ukraine, where the arid climate prevails [2]. Thus, it becomes relevant to analyze the prospects for desalination of the Black Sea and estuaries, in particular, for the needs of agriculture.

The technology of mechanical vapor compression (MVC) has several advantages over its main competitor - reverse osmosis (RO) technology. With comparable cost, MVC technology provides the best water quality. In addition, the installation of MVC is easier to use and does not require regular maintenance by the company of the manufacturer of membranes.

Installations with mechanical compression of steam of small capacity are autonomous and economically profitable, and can be used for irrigation of agricultural lands, water supply of houses, hotels, etc.

A stationary mathematical model of a desalination plant with mechanical vapor compression was developed in [3, 4]. However, the real process in such installations is non-stationary. The temperature rise in the system will continue until it is balanced by the loss of heat to the environment. Without taking into account the losses, the iterative process of solving the equations proposed in [3, 4], in a number of cases, led to a "trivial" zero solution.

Therefore, in [5], the "excess power" parameter was introduced, which allowed for the convergence of the solution of the system of equations in the entire range investigated. However, in all previously performed calculations, only one value of the mass salinity of sea water was taken in [3 - 5] $4.2 \%$, which corresponds to the conditions of the Red Sea.

The purpose of the article is to determine the optimal operating conditions for desalination plants using mechanical vapor compression (MVC), using the previously developed mathematical 
model, for different salinity of sea water corresponding to different water bodies of the World Ocean, in particular, to estimate the cost of desalinated water for the Black Sea.

To achieve this goal, operational parameters have been identified that have the most significant effect on desalinated water cost. The influence of these parameters on the resulted capital costs and operational costs is investigated.

Materials and methods. The effect of sea water salinity on the operation of the desalination plant is determined by the BPE parameter - the boiling point increase compared to the boiling point of fresh water. This value can be calculated with the help of the system of equations [4], rewritten taking into account the rules for computing polynomials:

$$
\begin{gathered}
A=\left(4,02 \cdot 10^{-6} T+1,883 \cdot 10^{-4}\right) T+8,25431 \cdot 10^{-2} \\
B=\left(-5,2 \cdot 10^{-7} T+9,02 \cdot 10^{-5}\right) T-7,625 \cdot 10^{-4} \\
C=\left(-3 \cdot 10^{-8} T-3 \cdot 10^{-6}\right) T+1,522 \cdot 10^{-4} \\
B P E=((C X+B) X+A) X
\end{gathered}
$$

where $B P E$ - boiling point increase, ${ }^{\circ} \mathrm{C}$;

$T$ - boiling point, ${ }^{\circ} \mathrm{C}$;

$X$ - mass salinity, \%.

Fig. 1 shows graphs of dependence of the BPE parameter against salt content at a constant temperature of brine

An analysis of the effect of various operating parameters showed that the cost of water is affected not directly by the salt content of seawater $X_{f}$, but by the salt content of the boiling solution in the evaporator $X_{b}$.

As some of the incoming seawater evaporates, the concentration $X_{b}$ is always greater than $X_{f}$. During the opera-

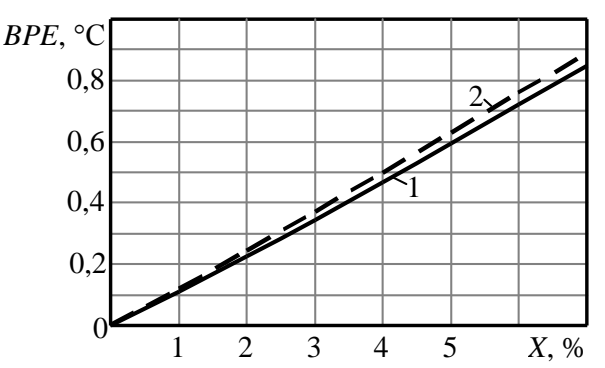

Fig. 1. Dependence of the BPE parameter on salt content at a constant temperature of brine $T=60$ (1), $70{ }^{\circ} \mathrm{C}(2)$ tion of the desalination plant, the concentration $X_{b}$ is determined by the consumption of the feeding sea water $M_{f}$. The relationship between these parameters follows from the equations of conservation of mass of water and salt:

$$
\frac{M_{f}}{M_{b}}=\frac{X_{b}}{X_{b}-X_{f}},
$$

where $M_{f}$ - mass flow of incoming sea water, $\mathrm{kg} / \mathrm{s}$;

$M_{d}$ - mass flow of produced distillate, $\mathrm{kg} / \mathrm{s}$.

When selecting the operating modes of the desalination plant, it is necessary to minimize scale deposition on the evaporator walls. As is known, at the boiling point of the brine up to $75^{\circ} \mathrm{C}$, calcium carbonate deposition prevails, from $75^{\circ} \mathrm{C}$ to about $110{ }^{\circ} \mathrm{C}$ - magnesium hydroxide, and over $110{ }^{\circ} \mathrm{C}-$ sedimentation of sulfate scale [6].

In most ship desalination plants it is recommended to maintain the boiling point $T_{b}$ not higher than $70{ }^{\circ} \mathrm{C}$ by creating an appropriate vacuum in the installation [6]. These recommendations are consistent with the data in [4], where in the calculated examples, oriented to practical application, the temperature of the boiling brine is $60^{\circ} \mathrm{C}$, and the salt content is $7 \%$.

Fig. 2 shows the cost ratios $M_{f} / M_{d}$ that provide a given concentration of brine $X_{b}$ with salt content of seawater of $1.8 \%$.

The methodology for calculating the annual costs for the production of desalinated water is given in [5]. According to accepted assumptions, all incoming seawater is heated to the temperature of boiling brine in the evaporator $T_{b}$. After evaporation of a part of the water, the leaving brine must give off 
the heat to the incoming seawater. Therefore, an increase in the flow rate of the feeding sea water $M_{f}$ requires a significant increase in the area of the preliminary heat exchangers.

The methodology takes into account all capital and operating costs, with the exception of personnel costs, which are determined not by the technical parameters of the installation, but by the size of the enterprise, the legislation of the country, and so on.

As the objective optimization function, by analogy with the way it was done in most publications (for example, in [7]), the cost of one cubic meter of desalinated water was chosen. Recalculation of annual costs to the cost of one cubic meter of water was carried out on condition that the desalination plant works 22 hours in a day and 360 days in a year.

The effect on the target function of the specific area of the evaporator-condenser and the salt content of the boiling solution was considered. In connection with the technical features,

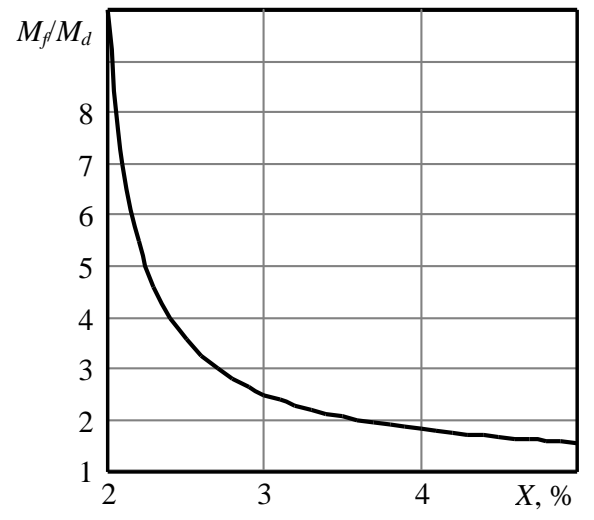

Fig. 2. Dependence of the ratio of water discharge $M_{f} / M_{d}$ on saline content of boiling brine $X_{b}$ with salinity of sea water $X_{f}=1.8 \%$ one-dimensional optimization was performed for each of these parameters.

One of the most important parameters affecting the cost of water is the area of the evaporator-condenser (hidden heat exchanger) $A_{e}$, related to the apparatus with a capacity of $1 \mathrm{~kg} / \mathrm{s}$. According to the method used, by setting this parameter, it is possible to unambiguously determine the required compressor power, the area of the auxiliary heat exchangers and the consumed electric power, and, consequently, the capital and operating costs.

In Fig. 3, as an example, the dependencies of the resulted capital costs, operating costs and total costs on the evaporator-condenser specific area $A_{e}$ calculated for salt content of sea water $X_{f}=1.8 \%$ (Black Sea) and saline content of boiling brine $X_{b}=2.7 \%$ are shown as an example.

From Fig. 3 that when the surface area of heat exchange of the evaporator-condenser increases, the capital costs increase due to the increase in the cost of the heat exchanger. But at the same time, operating costs are reduced due to a reduction in electricity consumption.

In the investigated range, the curve of the resulted total costs does not have an explicit minimum. However, the specific surface areas of the evaporator-condenser over $1000 \mathrm{~m}^{2}$ are recognized as unrealistic, since this leads to an increase in the cost of transportation and installation of equipment not directly accounted for in this model.

Fig. 4 shows the dependence of the resulted total costs on the relative area of the heat exchanger at $X_{f}=1.8 \%$ (Black Sea) and for different values $X_{b}$

Fig. 4 shows that the total costs are minimal, when $X_{b}$ is about $3 \%$.

Further calculations were carried out for a constant heat exchange surface of the evaporatorcondenser $A_{e}=1000 \mathrm{~m}^{2}$. Fig. 5 shows the dependence of the total costs of $C$ on $X_{b}$ for the conditions of the Black and Mediterranean Seas and the Persian Gulf.

From Fig. 5 it can be seen that to each value of salinity of sea water $X_{f}$ there corresponds some optimum value of the salinity of the boiling brine $X_{b}$. It is also clear that under the conditions of the Black Sea, the lowest cost of desalinated water can be achieved - about $0.41 \mathrm{USD} / \mathrm{m}^{3}$.

In Fig. 6, the optimum saline content of boiling brine is presented as a function of salt content of the feeding sea water.

Optimal values can be approximated by a linear relationship $X_{b}=5,0292+1.2138 X_{f}$.

The coefficient of determination of the obtained equation $R^{2}$ is close to unity ( $R^{2}=0.9996$ ), which indicates a good correspondence between the approximating dependence and the initial points. 
The optimal salt content of the brine can be maintained by adjusting the flow rate of the seawater supply in accordance with the formula (1). For example, from Fig. 2 it can be seen that the salinity of sea water $X_{f}=1.8 \%$ and the optimum value $X_{b}=2.7 \%$ corresponds to $\frac{M_{f}}{M_{b}}=3$

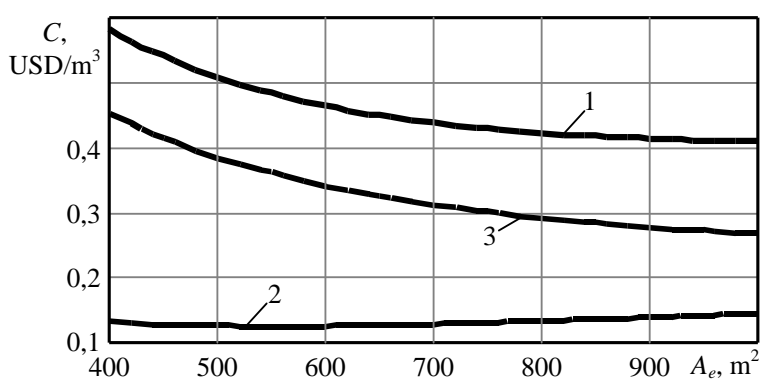

Fig. 3. Dependence of capital costs, operating costs and total costs on the specific heat exchange area in the evaporator-condenser: given total annual costs (1); given capital costs (2); operation unit costs (3)

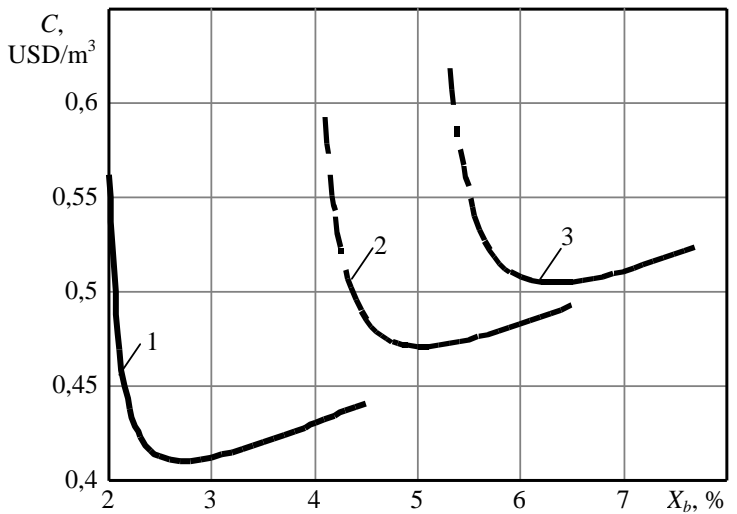

Fig. 5. Dependence of the cost of desalinated water $C$ on the salinity of boiling brine $X_{b}: X_{f}=1.8$ (Black

Sea) (1); 3.7 (Mediterranean Seas) (2); $4.8 \%$ (Persian Gulf ) (3)

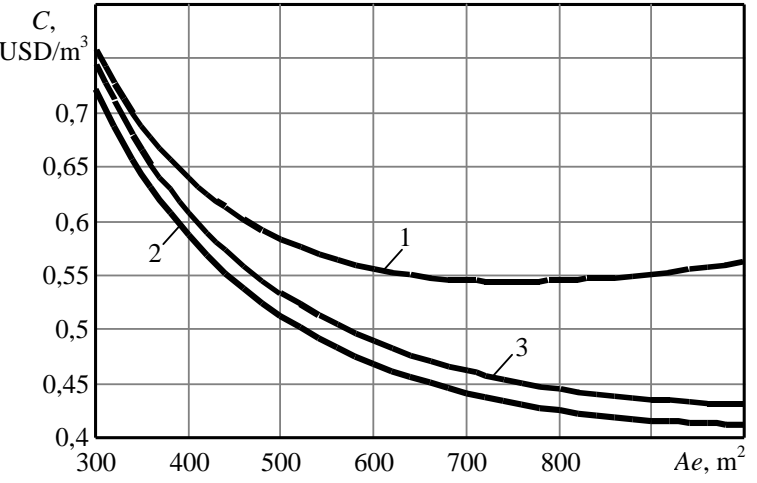

Fig. 4. Dependence of the total cost of $1 \mathrm{~m}^{3}$ of desalinated water at $X_{f}=1.8 \%$ and different values of salt content of boiling brine, $X_{b}=2$ (1); 3 (2); $4 \%$ (3)

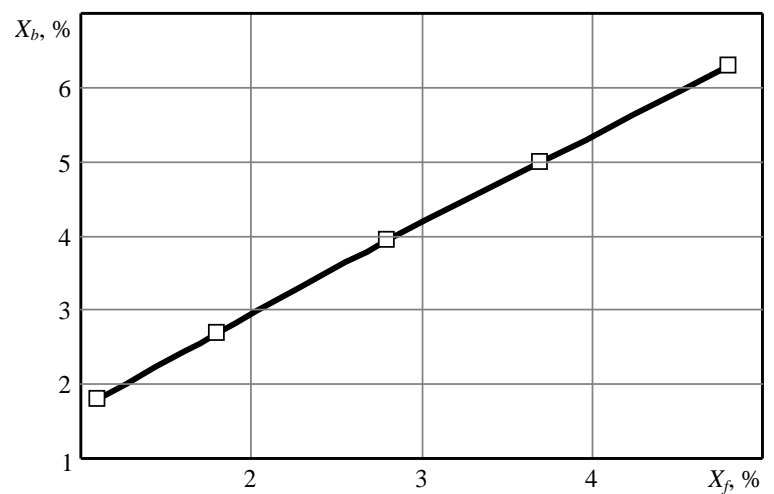

Fig. 6. Optimal salinity values for brine $X_{b}$ for different values $X_{f}$

Conclusions. Mathematical modeling of desalination plants with MVC makes it possible to determine their optimum operating parameters for desalination of water from various reservoirs.

One of the most important factors affecting the cost of desalinated water is the salt content of the brine boiling in the evaporator. Calculations have shown that to each value of salinity of sea water $X_{f}$ there corresponds some optimum value of the salinity of the boiling brine $X_{b}$. An approximating dependence for the optimum salt content of the brine is obtained.

The desalination of the Black Sea water using MVC facilities, for example for agricultural needs, can become economically profitable in the coming decades due to the low salt content of seawater. However, the obstacle to the wide introduction of MVC installations is that there are no compressors with a water vapor compression ratio of 1.1..1.2 operating in the presence of a vacuum of the order of 0.8...0.9 bar both at the inlet and outlet. 


\section{Література}

1. Escobar, I.C. Sustainable water for future: water recycling versus desalination. / I.C. Escobar, A.I. Schäfer. - Amsterdam: Elsevier, 2010. - 416 p. - ISBN: 978-0-444-53115-5.

2. Тенденції змін планетарного клімату та їх можливого впливу на основні сектори української економіки / за ред. Хвесика М.А. - К.: Логос, 2012. - 268 с.

3. Al-Juwayhel, F. Analysis of single-effect evaporator desalination systems combined with vapor compression heat pumps / F. Al-Juwayhel, H. El-Dessouky, H. Ettouney // Desalination. - 1997. - Vol. 114, Issue 3. - PP. $253-275$.

4. El-Dessouky, H.T. Fundamentals of sea water desalination. / H.T. El-Dessouky, H.M. Ettouney. - Amsterdam: Elsevier, 2002. - 670 p. - ISBN: 0-444-50810-4.

5. Kravchenko, V.P., Surkov S.V., Ghanem Hussam. Modelling and optimization of seawater desalination process using mechanical vapor compression / V.P. Kravchenko, S.V.Surkov, Ghanem Hussam // Odes’kyi Politechnichnyi Universytet. Pratsi. - 2016, Issue 2(49), DOI 10.15276/opu.2.49.2016.08.

6. Коваленко, В.Ф. Судовые водоопреснительные установки / В.Ф. Коваленко, Г.Я. Лукин. - Л.: Судостроение, 1970. - 304 с.

7. Lara, J.R. Advanced Mechanical Vapor-Compression Desalination System. [Електронний ресурс] / J.R. Lara, O. Osunsan, M.T. Holtzapple // Desalination, Trends and Technologies, Michael Schorr (Ed.), ISBN: 978-953-307-311-8, InTech, 2011. Режим доступу: http://www.intechopen.com/books/ desalination-trends-andtechnologies/advanced-mechanical-vapor-compression-desalination-system

\section{References}

1. Escobar, I.C., \& Schäfer, A.I. (2010). Sustainable Water for the Future: Water Recycling Versus Desalination. Amsterdam: Elsevier.

2. Khvesik, M.A. (Eds.). (2012). Tendentsiyi zmin planetarnoho klimatu ta yikh mozhlyvoho vplyvu na osnovni sektory ukrayins'koyi ekonomiky [Trends in global climate changes and their possible impact on key sectors of the Ukrainian economy]. Kyiv: Logos.

3. Al-Juwayhel, F., El-Dessouky, H., \& Ettouney, H. (1997). Analysis of single-effect evaporator desalination systems combined with vapor compression heat pumps. Desalination, 114(3), 253-275. DOI:10.1016/S0011-9164(98)00017-4

4. El-Dessouky, H.T., \& Ettouney, H.M. (2002). Fundamentals of Salt Water Desalination. Amsterdam: Elsevier.

5. Kravchenko, V.P., Surkov, S.V. \& Ghanem, Hussam (2016). Modelling and optimization of seawater desalination process using mechanical vapor compression. Odes'kyi Politechnichnyi Universytet. Pratsi, 2(49), 47 - 55. DOI: 10.15276/opu.2.49.2016.08.

6. Kovalenko, V.F., \& Lukin G.Ya. (1970). Sudovyye vodoopresnitel'nyye ustanovki [Ship water desalination plants]. Leningrad: Sudostroyeniye.

7. Lara, J.R., Osunsan, O., \& Holtzapple, M.T. (2011) Advanced Mechanical Vapor-Compression Desalination System. Michael Schorr (Ed.) Desalination, Trends and Technologies. Retrieved from http://www.intechopen.com/books/desalination-trends-andtechnologies/advanced-mechanical-vaporcompression-desalination-system 